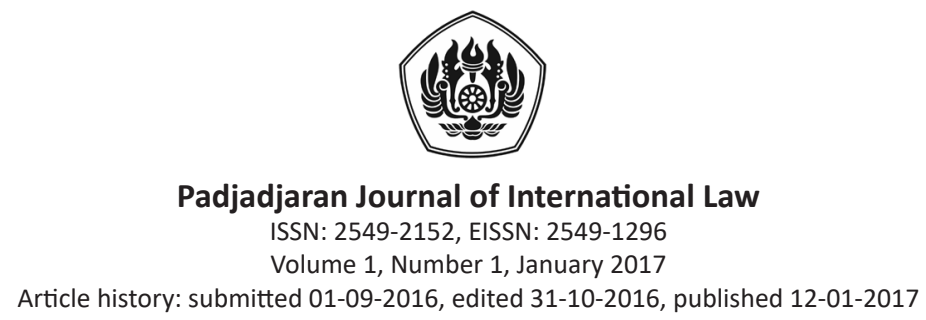

\title{
Marine Renewable Energy, the Law of the Sea and the Marine Environment: An Indonesian Perspective
}

\author{
Gusman Siswandi
}

\begin{abstract}
According to the report of the Secretary-General of the United Nations, there are at least three benefits of marine renewable energy. From an environmental perspective, the utilization of marine renewable energy could reduce dependency upon conventional energy sources, especially the non-renewable ones. From an economic perspective, the renewable energy projects have developed significantly both in developed and developing countries. It was estimated that global investments in the renewable energy sector increased by $32 \%$ in 2010, reaching the total figure of $\$ 2.11$ billion. Although there have not been any statistics available for marine renewable energy, this figure could provide an indication for the prospects of marine renewable energy in the future. This article aims to identify and to analyze legal aspects related to the utilization of marine renewable energy in Indonesia, particularly in the contexts of the law of the sea and the marine environment. Since marine renewable energy in Indonesia is still developing, it is necessary to ensure that all activities pertaining to the utilization of marine renewable energy resources are conducted in accordance with prevailing laws and regulations. In this regard, the 1982 United Nations Convention on the Law of the Sea (UNCLOS) is one of the main legal instruments that need to be considered by coastal States in utilizing marine renewable energy. This study finds that the current laws and policy in Indonesia are still inadequate to regulate the development of marine renewable energy. The National Energy Policy only provides a broad and general policy on renewable energy sources and does not cover a particular strategy on marine renewable energy. Thus, the Indonesian Government needs to establish a specific policy on marine renewable energy as well as specific laws and regulations to address the environmental impacts that may result from marine renewable energy activities.
\end{abstract}

Keywords: marine renewable energy, law of the sea, marine energy, indonesian perspective.

\section{Energi Laut Terbarukan, Hukum Laut dan Lingkungan Laut: Perspektif Indonesia}

\begin{abstract}
Abstrak
Berdasarkan laporan dari Sekjen PBB, sekurang-kurangnya terdapat tiga keuntungan dari energi laut terbarukan. Dari perspektiflingkungan, pemanfaatan energi laut terbarukan dapat mengurangi ketergantungan terhadap energi konvensional, khususnya yang tidak terbarukan. Dari perspektif
\end{abstract}

\footnotetext{
* Lecturer at Faculty of Law Universitas Padjadjaran, Jl. Dipati Ukur No. 35 Bandung, ahmad.gusman@unpad.ac.id, S.H. (Universitas Padjadjaran), LL.M. (University College London), Ph.D. (Australian National University).
} 
ekonomi, proyek energi terbarukan telah berkembang cukup signifikan, baik di negara berkembang maupun negara maju. Secara global, diperkirakan telah terdapat kenaikan investasi sebesar 32\% di tahun 2010, hingga mencapai 2.11 miliar US Dolar. Meskipun belum ada statistik yang pasti, akan tetapiangka tersebut sudah menggambarkan prospek perkembangan energi terbarukan di masa yang akan datang. Artikel ini bertujuan untuk menganailisa aspek hukum yang berkaitan dengan pemanfaatan energi laut terbarukan di Indonesia, khususnya dalam konteks hukum laut dan lingkungan laut. Sejak energi laut terbarukan berkembang di Indonesia berkembang, sangatlah diperlukan agar pengeturan kegiatan tersebut sesuai dengan peraturan perundangundangan. Berkenaan dengan ini, Konvensi Hukum Laut 1982 adalah salah satu dari intrumen hukum yang harus diperhatikan oleh negara pantai dalam menjalankan kegiatan pemanfaatan energi laut terbarukan. Kebijakan Energi Nasional hanya menyediakan kebijakan nasional yang sifatnya umum dalam pemanfaatan energi laut terbarukan. Dengan demikian Indonesia perlu membentuk kebijakan yang lebih spesifik berkenaan dengan pemanfaatan energi laut terbarukan, khususnya dampak lingkungan terhadap pemanfaatan energi laut terbarukan.

Kata kunci: energi laut terbarukan, hukum laut, energi laut, sudut pandang indonesia.

\section{A. Introduction}

"Energy is the golden thread that connects economic growth, increased social equity, and an environment that allows the world to thrive. Development is not possible without energy, and sustainable development is not possible without sustainable energy." ${ }^{1}$

Global environmental problems, coupled with economic and humanitarian crises in many parts of the world, have urged the international community to address a number of issues crucial to human survival, including energy. In 2011, the United Nations Secretary General Ban Ki-moon launched a global initiative called "Sustainable Energy for All", which is expected to mobilize action from all sectors in support of three objectives, namely: providing universal access to modern energy services; doubling the global rate of improvement in energy efficiency; and doubling the share of renewable energy in the global energy mix. ${ }^{2}$ In its 2012 report, the High Level Group on Sustainable Energy for All has elaborated the role of energy in supporting development, and sustainable energy is undoubtedly required to achieve sustainable development. $^{3}$

Although the report underscores the important role of renewable energy, nonrenewable or conventional energy sources, such as oil, gas and coal, still dominate the global energy consumption. Nevertheless, there has been a gradual shift from the utilization of nonrenewable energy to renewable energy sources within the last decade. For instance, Herzog, Lipman dan Kammen observed that:

"Conventional energy sources based on oil, coal, and natural gas have proven to be highly effective drivers of economic progress, but at the same time damaging to the environment and to human health. ... These traditional fossil fuel-based

\footnotetext{
${ }^{1}$ The Secretary General's High-Level Group on Sustainable Energy for All, Sustainable Energy for All: A Global Action Agenda, New York: United Nations, 2012, p. 3.

2 Sustainable Energy for All, About Us <http://www.se4all.org/about-us/> (2 February 2015).

${ }^{3}$ The Secretary General's High-Level Group on Sustainable Energy for All, loc.cit.
} 
energy sources are facing increasing pressure on a host of environmental fronts, with perhaps the most serious challenge confronting the future use of coal being the Kyoto Protocol greenhouse gases (GHG) reduction targets." ${ }^{4}$

In this regard, renewable energy sources hold a strategic value, particularly from an environmental perspective. This has been elaborated in the 2002 Johannesburg Plan of Implementation (JPOI), which enumerates global commitments to implement the elements of sustainable development ten years after the 1992 United Nations Conference on Environment and Development (UNCED). The JPOI explicitly discusses renewable energy within numerous contexts, including: poverty eradication; changing patterns of consumption and production; and sustainable development in certain countries and regions, including the African and small island developing States. ${ }^{5}$ For instance, the JPOI urges governments and stakeholders to take necessary steps in promoting research and development in the field of renewable energy, as follows:

"Promote increased research and development in the field of various energy technologies, including renewable energy, energy efficiency and advanced energy technologies, including advanced and cleaner fossil fuel technologies, both nationally and through international collaboration; strengthen national and regional research and development institutions/ centres on reliable, affordable, economically viable, socially acceptable and environmentally sound energy for sustainable development." ${ }^{16}$

Following the commitments made under the JPOI 2002, the international community adopted The Future We Want through the Rio+20 Forum held in Brazil in 2012 to commemorate 20 years of UNCED. In the context of renewable energy, the document stated:

"We reaffirm support for the implementation of national and subnational policies and strategies, based on individual national circumstances and development aspirations, using an appropriate energy mix to meet developmental needs, including through increased use of renewable energy sources and other low-emission technologies, the more efficient use of energy, greater reliance on advanced energy technologies, including cleaner fossil fuel technologies, and the sustainable use of traditional energy resources."7

Thus, both JPOI and The Future We Want acknowledge the strategic role of renewable energy in achieving the objectives of sustainable development. Recently, the importance of renewable energy in supporting sustainable development has been also reaffirmed through the Sustainable Development Goals that was adopted in the United Nations summit for

\footnotetext{
${ }^{4}$ Antonia V. Herzog, Timothy E. Lipman, Daniel M. Kammen, Renewable Energy Sources <www-fa.upc.es/personals/fluids/oriol/ale/ eolss.pdf>, p. 9 (24 March 2014).

${ }^{5}$ United Nations General Assembly, Oceans and the Law of the Sea-Report of the Secretary-General (UN Doc. A/67/79, 4 April 2012), par. 69.

${ }^{6}$ Plan of Implementation of the World Summit on Sustainable Development <http://www.un.org/esa/sustdev/documents/WSSD_POI_ PD/English/WSSD_PlanImpl. pdf>, par. 20(k) (24 March 2014).

${ }^{7}$ The Future We Want, UN Doc A/RES/66/288, 11 September 2012, par. 127.
} 
Marine Renewable Energy, the Law of the Sea and the Marine Environment: An Indonesian Perspective

the adoption of the post-2015 development agenda. ${ }^{8}$ Under Goal 7 on "Ensure access to affordable, reliable, sustainable and modern energy for all", the international community has committed to reach the following goals:

"7.a By 2030, enhance international cooperate to facilitate access to clean energy research and technology, including renewable energy, energy efficiency and advanced and cleaner fossil-fuel technology, and promote investment in energy infrastructure and clean energy technology.

7.b By 2030, expand infrastructure and upgrade technology for supplying modern and sustainable energy services for all in developing countries, in particular least developed countries, small island developing States and landlocked developing countries, in accordance with their respective programmes of support." ${ }^{\prime 9}$

There are several forms of renewable energy, including biomass, wind, solar, hydropower, and geothermal. ${ }^{10}$ The oceans have also been considered as one of the potential sources of renewable energy, particularly those generated from current, wind, and thermal. The earliest form of marine renewable energy is the ocean thermal energy conversion (OTEC), which was developed between 1960s-1980s. ${ }^{11}$
Currently, marine renewable energy technology has been directed towards current and hydrokinetic. ${ }^{12}$

According to the report of the SecretaryGeneral of the United Nations, there are at least three benefits of marine renewable energy. From an environmental perspective, the utilization of marine renewable energy could reduce dependency upon conventional energy sources, especially the non-renewable ones. ${ }^{13}$ From an economic perspective, the renewable energy projects have developed significantly both in developed and developing countries. It was estimated that global investments in the renewable energy sector increased by $32 \%$ in 2010 , reaching the total figure of $\$ 2.11$ billion. ${ }^{15}$ Although there have not been any statistics available for marine renewable energy, this figure could provide an indication for the prospects of marine renewable energy in the future. $^{16}$

From a social perspective, marine renewable energy would provide realistic and sustainable solutions especially for coastal communities who generally have limited or do not have any access to modern energy services. ${ }^{17}$ Thus, the development of marine renewable energy sector could provide a significant contribution to social economic development, particularly in developing countries. ${ }^{18}$

\footnotetext{
8 United Nations General Assembly, Draft Outcome Document of the United Nations Summit for the Adoption of the Post-2015 Development Agenda (UN Doc. A/69/L.85, 12 August 2015).

${ }^{9}$ Idem., p. 19.

${ }^{10}$ See, eg, Antonia V. Herzog, Timothy E. Lipman, Daniel M. Kammen, loc.cit.

${ }^{11}$ David Leary and Miguel Esteban, "Climate Change and Renewable Energy from the Ocean and Tides: Calming the Sea of Regulatory Uncertainty" (2009) 24 Marine and Coastal Law 617, p. 618.

12 Idem, p. 618-619.

${ }^{13}$ United Nations General Assembly, op.cit., par. 70.

${ }^{14}$ Idem, par. 73

${ }^{15} \mathrm{Ibid}$.

${ }^{16}$ Idem, par. 75 .

${ }^{17}$ Idem, par. 76.

${ }^{18}$ Idem, par. 77.
} 
In the Indonesian context, the ratio of electricity was targeted to reach $81,4 \%$ from all household, while the National Development Planning only targeted $80 \% .{ }^{19}$ Such a high target needs to be supported by the availability of energy sources. Being the largest archipelagic State in the world, with two-thirds of its area covered with waters, Indonesia undoubtedly has a great potential in marine renewable energy resources. Nonetheless, Indonesia still largely depends on non-renewable energy as Mujiyanto and Tiess observed:

"Indonesia's strong economic growth caused an even faster increase demand for energy. From 1980 to 2010, total primary energy production grew 2.8 times, while energy consumption grew to almost five times. In 2010, approximately $96 \%$ of the national energy mix was dominated by fossil fuels. The renewable sources, mainly hydropower and geothermal energy, amounted to less than $4 \%$. Total energy demand in 2025 is predicted to be nearly 3 times higher than that in 2010 . The problem of natural depletion of nonrenewable resources, particularly oil, and their compensation has to be solved."20

Futhermore, Mujiyanto and Tiess also noted that marine energy resources in Indonesia have not been commercially developed. ${ }^{21}$

Against this background, this article aims to identify and to analyze legal aspects related to the utilization of marine renewable energy in Indonesia, particularly in the contexts of the law of the sea and the marine environment.
Since marine renewable energy in Indonesia is still developing, it is necessary to ensure that all activities pertaining to the utilization of marine renewable energy resources are conducted in accordance with prevailing laws and regulations. In this regard, the 1982 United Nations Convention on the Law of the Sea (UNCLOS) is one of the main legal instruments that need to be considered by coastal States in utilizing marine renewable energy.

UNCLOS provides legal framework for coastal States in exercising their sovereignty and jurisdiction in various maritime zones, and this may affect the legal status of marine energy installations. In addition, UNCLOS requires states to ensure that the utilization of marine resources does not cause harm to the marine environment; thus is also necessary to ensure that activities related to marine renewable energy are conducted in line with the protection and preservation of the marine environment. This particular aspect will be the main focus of this article.

This article will be divided in three parts. The first part will discuss relevant provisions of UNCLOS related to the development of marine renewable energy. The second part will discuss the current situation with respect to marine renewable energy in Indonesia. The third part will discuss measures that need to be taken by the Indonesian Government in ensuring that activities related to marine renewable energy are conducted in line with the protection and preservation of the marine environment.

\footnotetext{
${ }^{19}$ Dewan Energi Nasional, R-Pengaturan Pemerintah Kebijakan Energi Nasional, p. 15 <http://pse.ugm.ac.id/wp/wp-content/uploads/ Peraturan-Pemerintah-KEBIJAKAN-ENERGI-NASIONAL-RPP-KEN.pdf> (20 November 2014).

${ }^{20}$ Sugeng Mujiyanto and Günter Tiess, “Secure Energy Supply in 2025: Indonesia's Need for an Energy Policy Strategy” (2013) 61 Energy Policy 31, p. 31.

${ }^{21}$ Idem, p. 35.
} 
Marine Renewable Energy, the Law of the Sea and the Marine Environment: An Indonesian Perspective

B. Marine renewable energy, the law of the sea and the marine environment

Current and hidrokinetic energy installations, for example, are established within internal waters and therefore subject to full sovereignty of the coastal State. ${ }^{22}$ However, if marine energy installations are located in the territorial sea, then it would raise an issue whether such installations could disrupt navigational activities conducted therein. ${ }^{23}$ In this context, there are some important provisions under UNCLOS that apply, especially article 17 (innocent passage); article 21 (laws and regulations of coastal States related to innocent passage); and article 22 (traffic separation schemes in territorial sea). ${ }^{24}$

The Coastal State may also exercise its rights regarding marine energy installations located in the Exclusive Economic Zone (EEZ). According to UNCLOS, the Coastal State has a sovereign right to explore and exploit, both living and non-living resouces, including exploration and exploitation activities with respect to other economic activities, such as energy utilization from water, current and wind. ${ }^{25}$ In addition, the coastal State has an exclusive right to construct, allow and regulate the installations established to utilize natural resources in their EEZ. ${ }^{26}$

Within the fields of the environment and sustainable development, the promotion and development of renewable energy also play a significant role in addressing global

\footnotetext{
${ }^{22}$ David Leary and Miguel Esteban, op.cit., p. 631.

${ }^{23}$ See Leary dan Esteban, op.cit., p. 632-636.

${ }^{24} \mathrm{Ibid}$.

${ }^{25}$ UNCLOS, Article 56.1 (a).

${ }^{26}$ UNCLOS, Article 60.1 (b)

${ }^{27}$ George W. Boehlert and Andrew B. Gill, "Environmental and Ecological Effects of Ocean Renewable Energy Development: A Current Synthesis" (2010) 23 Oceanography 68, p. 68.

${ }^{28} \mathrm{Ibid}$.

${ }^{29}$ Idem, p. 71-78.

${ }^{30}$ Mark A. Shields, et.al., "Marine Renewable Energy: The Ecological Implications of Altering the Hydrodynamics of the Marine Environment" (2011) 54 Ocean and Coastal Management 2-9.
}

environmental issues, especially climate change. As Boehlert and Gill observed:

"Renewable energy resources may for reducing our substantial contribution to global warming. ... Technology to capture the energy from wind, the sun, and biomass are all in various stages of development. In many areas of the world, marine renewable energy has great promise but many of the approaches remain to be developed to commercial standards." 27

Nonetheless, Boehlert and Gill argued that despite this important role, the development of marine renewable energy may also cause adverse impacts to the marine environment. ${ }^{28}$ Therefore, states and other stakeholders need to take measures with regard to environmental impacts from marine renewable energy development. In this regard, Boehlert and Gill further studied a number of effects and impacts that may result from marine renewable energy activities, including: chemical impacts; acoustic impacts and altered habitat composition surrounding energy installations. ${ }^{29}$

Other scholars have also conducted studies on the impact of marine renewable energy development to the marine environment. For instance, a study by Shields, et.al., found that the extraction of energy from waves will reduce their energy and heights. ${ }^{30}$ Consequently, it represent one of humankind's best hopes 
will have an impact on some species that have adapted to the waves conditions. Nonetheless, further studies are still needed to determine suitable ecological response to such changes, which may also be variable. ${ }^{32}$

Furthermore, Costelos observed the adverse impacts of marine renewable energy activities to the marine environment as follow:

- "the alteration of benthic habitats and sediment transport or deposition by the construction activities and continuous presence of devices and structures;

- deaths or changes in the behaviour of fish and mammals as a result of noise and electromagnetic fields;

- interference with the movement, feeding, spawning, and migration paths of fish, mammals, and birds;

- the release of toxic chemicals as a result of accidental spills, or leaks, or the accumulation of metals or organic compounds; and

- the reduction of the velocity of marine currents and decreases in wave height resulting from the extraction of wave or tidal energy." ${ }^{33}$

Another study by Inger, et.al. found that on one hand, marine renewable energy installations could cause adverse impacts to the marine environment, including: habitat loss; collision risks; noise and electromagnetic fields. ${ }^{34}$ On the other hand, marine renewable energy activities could have positive impacts on marine biodiversity, for instance as artificial reefs and marine protected areas. ${ }^{35}$

It could be concluded from these studies that while marine renewable energy could provide significant contribution to sustainable energy, it also poses certain risks to the marine environment. Thus, it is necessary to take into account the relevant UNCLOS provisions, particularly Article 192, which provides that all States have obligation to protect and preserve the marine environment. ${ }^{36}$ Specifically, UNCLOS also obliges States to take necessary measures to ensure that activities within their jurisdiction do not cause damage or pollution to other States or areas beyond national jurisdiction. ${ }^{37}$

These measures include, among others, response measures for pollution from marine installations, including measures to prevent accidents, safety operations, and regulations on design, construction and equipment. ${ }^{38}$ Thus, coastal States need to implement this provision to ensure that marine renewable energy installations located within their national jurisdiction would not cause damage or pollution to the marine environment.

In this regard, the impacts of marine renewable energy activities have been discussed in several international fora, including the United Nations Open-ended Informal Consultative Process on Oceans

${ }^{31}$ Idem, p. 7.

32 Ibid.

${ }^{33}$ Montserrat Abad Castelos, "Marine Renewable Energies: Opportunities, Law, and Management" (2014) 45 Ocean Development and International Law 221, p. 226, quoting Report of the UN Secretary General, Oceans and the Law of the Sea, UN Doc. A/67/79, p. 22.

${ }^{34}$ Richard Inger, et.al., "Marine Renewable Energy: Potential Benefits to Biodiversity? An Urgent Call for Research" (2009) 46 Journal of Applied Ecology 1145, p. 1145.

${ }^{35}$ Ibid.

${ }^{36}$ UNCLOS, Article 192.

${ }^{37}$ UNCLOS, Article 194.2.

${ }^{38}$ UNCLOS, Article 194.3. 
Marine Renewable Energy, the Law of the Sea and the Marine Environment: An Indonesian Perspective

and the Law of the Sea (UNICPOLOS). At its thirteenth meeeting in 2012, the UNICPOLOS observed main environmental issues that need to be considered in the management of marine renewable energy, which include:

a. The conflict management regarding the use of the ocean, namely the possible conflict between areas allocated for marine renewable energy and areas allocated for other activities, such as fisheries; and

b. The impact of marine renewable energy installation to shipping activities and the marine environment, including environmental impacts from the OTEC. ${ }^{39}$

\section{Marine renewable energy in Indonesia}

According to the Association of Indonesian Marine Energy (Asosiasi Energi Laut Indonesia/ ASELI), in theory, the potential of Indonesian marine energy comprises $510 \mathrm{GW}$ (tide), 160 GW (current), and $57 \mathrm{GW}$ (thermal). ${ }^{41}$ With the current technology available, the potential of Indonesian marine energy in practice could reach up to $49 \mathrm{GW}$, including $1.2 \mathrm{MW}$ (tide), 4.8 $\mathrm{GW}$ (current), and $43 \mathrm{GW}$ (thermal). ${ }^{41}$ Based on these figures, marine renewable energy could secure future energy supply if it is optimally utilized. In this regard, the Indonesian Agency for Assessment and Application of Technology (Badan Pengkajian dan Penerapan Teknologi/ BPPT) have conducted research on more than fifteen locations throughout Indonesia that are potential for the development of marine renewable energy, especially current and OTEC. ${ }^{42}$ In addition, the Ministry of Energy and Mineral Resources currently has developed a pilot plant of $1 \mathrm{MW}$ ocean current energy between Nusa Lembongan and Nusa Ceningan, in Bali.

Furthermore, several studies have been conducted with respect to the potentials of renewable energy in Indonesia. For example, Martosaputro and Murti have assessed the wind energy potential, particularly in the context of developing accessible energy for remote villages and areas in Indonesia. ${ }^{43}$ According to Martosaputro and Murti, the application of wind energy in Indonesia is still low, which is still only $1.6 \mathrm{MW}$ in approximate on noncommercial scale. In fact, the application of wind energy could reach up to $9.29 \mathrm{GW}$ if it is optimally utilized. ${ }^{44}$ Some obstacles in developing wind energy in Indonesia include: the level of reliability, financial support and policy support. ${ }^{45}$

In the field of marine renewable energy, Blunden, Bahaj, and Aziz have been specifically studied the potential of current and tidal energy in the Alas Strait. ${ }^{46}$ Their findings confirm that the potentials of current and tidal energy in the area could reach approximately $640 \mathrm{GW}$; however, further research are still needed to locate the most optimum area. ${ }^{47}$

\footnotetext{
${ }^{39}$ United Nations General Assembly, Report on the Work of the United Nations Open-ended Informal Consultative Process on Oceans and the Law of the Sea at its Thirteenth Meeting, UN Doc A/67/120, 2 July 2012, par. 38-43.

${ }^{40}$ Kementerian Riset dan Teknologi RI, Rancangan Peta jalan Regulasi Energi Laut, Jakarta, 2013, p. 11.

${ }^{41} \mathrm{lbid}$.

42 Ibid.

${ }^{43}$ Soeripno Martosaputro and Nila Murti, “Blowing the Wind Energy in Indonesia” (2014) 47 Energy Procedia 273 , p. 274.

${ }^{44} \mathrm{Ibid}$.

${ }^{45}$ Idem, p. 282.

${ }^{46}$ L.S. Blunden, A.S. Bahaj, N.S. Aziz, "Tidal Current Power for Indonesia? An Initial Resource Estimation for the Alas Strait" (2013) 49 Renewable Energy 137-142.

${ }^{47}$ Idem, p. 142.
} 
Indonesia currently has a number of laws and regulations concerning renewable energy. For instance, the Energy Act of 2007 acknowledges that since there is a limited supply of non-renewable energy, it is important to promote energy diversification to ensure the availability of energy resources. ${ }^{48}$ Furthermore, the Act also states that renewable energy resources is regulated by the state and utilized for enhancing people's welfare. ${ }^{49}$

The Indonesian Government has also enacted the Presidential Regulation (Peraturan Presiden) No. 5 of 2006 concerning National Energy Policy. The Regulation stipulates that one of the targets of national energy policy is an optimal primary energy mix in 2025, with the utilization of new and renewable energy that reach more than five percent. ${ }^{50}$ However, the Energy Act of 2007 stipulates that the national energy policy is determined by the government upon the approval from the House of Representatives (Dewan Perwakilan Rakyat). Therefore, the 2006 Presidential Regulation has now been replaced by the Government Regulation (Peraturan Pemerintah) No. 79 of 2014 concerning National Energy Policy. One of the aims of the Regulation is to optimize the utilization of renewable energy by taking into account the level of economic development. ${ }^{51}$ The utilization of marine renewable energy in particular is focused on the OTEC, current, and waves. $^{52}$
According to Mujiyanto and Tiess, the development of a clear and comprehensive renewable energy policy in Indonesia is urgently needed. ${ }^{53}$ Their studies find that from 1980 to 2010 , the total figure of energy production have increased 2.8 times, while the energy consumption have increased almost 5 times. ${ }^{54}$ Additionally, Indonesia still has a high level of dependency upon non-renewable energy resources, which have always depleted from year to year. ${ }^{55}$ Therefore, Mujiyanto and Tiess argued that to ensure the energy availability in 2025, it is essential for Indonesia to develop a national energy strategy that is based on appropriate energy mix. ${ }^{56}$

In this light, the Indonesian Government has taken a number of initiatives in the field of renewable energy. However, Mujiyanto and Tiess have questioned whether these initiatives have been managed appropriately. They argued: "Several actions and programmes have been implemented based on the energy policy and regulatory framework, and many of them in cooperation with friendly countries, international companies and organisations. The question arises if these are interrelated and coordinated. Also the question of efficiency is evident: The way of issuing regulations and making amendments during the process of implementation whenever the situation affords them, might be too inefficient

${ }^{48}$ The Energy Act, Preamble.

${ }^{49}$ The Energy Act, Article 4 (2).

${ }^{50}$ The Presidential Regulation No. 5 of 2006, Article 2 (2) b 6).

${ }^{51}$ Article 11 paragraph (2) a.

${ }^{52}$ Kementerian ESDM, Pokok-Pokok Kebijakan Energi Nasional <http://www.esdm.go.id/berita/56-artikel/3342-pokok-pokok-kebijakanenergi-nasional.html?tmpl=component\&print=1\&page=> accessed 20 November 2014

${ }^{53}$ Sugeng Mujiyanto and Günter Tiess, op.cit., p. 31.

${ }^{54} \mathrm{lbid}$.

55 Ibid.

56 Ibid. 
Marine Renewable Energy, the Law of the Sea and the Marine Environment: An Indonesian Perspective

and slow to solve the problem of rapidly growing domestic energy demand and imminent depletion of resources. ${ }^{\prime 57}$

Furthermore, despite the fact that the Indonesian Government has enacted several laws and regulations concerning renewable energy, there has not been any particular policy and regulation on marine renewable energy. In addition, the National Energy Management Blueprint of 2006-2025 does not specifically mention any plans regarding the management of marine renewable energy. These facts seem to contradict the Indonesia's potential in the utilization of marine renewable energy as the world's largest archipelagic country.

\section{Measures need to be taken by the Indonesian Government}

As a State Party to UNCLOS, Indonesia is bound by and obliged to implement its provisions. In the field of marine renewable energy activities, the Indonesian Government must ensure that such activities are conducted in line with UNCLOS. As far as the marine environment is concerned, the Indonesian Government needs to address at least two important issues. Firstly, a specific instrument on marine spatial law to regulate the allocation of marine energy installations and activities; and secondly, a specific instrument to regulate the environmental safety of the marine renewable energy installations and equipments. ${ }^{58}$ This section will discuss whether the current Indonesian laws and regulations have addressed these issues and what measures that still need to be taken by the Indonesian Government in this regard.

\footnotetext{
57 Sugeng Mujiyanto and Günter Tiess, op.cit, p. 40.

${ }^{58}$ See also Montserrat Abad Castelos, ibid.

${ }^{59}$ The Government Regulation No. 79 of 2014, Article 2.

${ }^{60}$ The Government Regulation No. 79 of 2014, Article 17 (3).

${ }^{61}$ The Government Regulation No. 79 of 2014, Article 19 (1), (2), (3).
}

\section{National Energy Policy}

The Government Regulation No. 79 of 2014 on National Energy Policy affirms that the energy policy in Indonesia is based on the principles of equity, sustainability, and environmental perspective. ${ }^{59}$ The principle of environmental perspective is further elaborated in Article 17 concerning Energy Conservation. Furthermore, the environmental aspect is also regulated under Article 19, which affirms the importance of spatial aspect and environment. ${ }^{60}$ It stipulates that:

(1) The national energy management is conducted in line with sustainable national development, preservation of natural resources, conservation of energy resources, and control of environmental impacts.

(2) The national energy activities must consider the factors of health, work safety, and social impacts by maintaining the environmental functions.

(3) Every activity regarding energy supply and utilization is required to:

a. conduct prevention, elimination, handling and recovery of the impacts, and provide fair compensation for injured parties;

b. minimize waste production, reuse waste in production process, reuse waste for other purposes, and extract useful waste components by considering relevant social, environmental and economic aspects; and

c. prioritize environmentally sound technologies. ${ }^{61}$

Although the National Energy Policy has addressed the environmental aspects related to 
the energy development, it does not explicitly regulate those aspects in the field of marine renewable energy.

Therefore, the current National Energy Policy needs to be amended by addressing a specific policy for environmental aspects on the utilization of marine renewable energy. Such a policy has been implemented for instance in the management of marine renewable energy in Nova Scotia, Canada, which reads as follows:

"The marine environment is complex and shared by many users. It is a public resource and as such the owners-Nova Scotiansmust trust how marine renewable energy is developed and operated to ensure sustainable and beneficial growth. Public acceptance and trust must be earned and maintained. A general understanding of the science and a transparent and accountable regulatory regime will help. Environmental monitoring and protection, public reporting, maintaining the highest standards of health and safety, and providing ongoing opportunities for public and stakeholder engagement are essential." ${ }^{\prime 62}$

In addition, the marine renewable energy policy in Nova Scotia takes into account the importance of an integrated approach:

"Constructing and operating renewable energy devices in a marine environment requires the coordination and integration of multiple federal and provincial interests. Once the industry begins to grow to largescale commercial development, there may be gaps in current legislation and potential for duplication that could increase the risk of inefficient regulatory oversight and important issues being missed due to confusion over roles and responsibilities." "63 Thus, the marine renewable energy policy of Nova Scotia has specifically addressed the unique and particular characteristic of the marine environment. Such an approach should also be applied in the development of marine renewable energy in Indonesia.

\section{The Energy Act}

The Act No. 30 of 2007 (the Energy Act) includes some provisions on environmental aspects of energy. It stipulates that the energy management is based on the principle of the preservation of environment ${ }^{64}$ dan aims to maintain the functions of the environment. ${ }^{65}$

Furthermore, the Energy Act provides that:

(1) Every energy management activity must prioritize environmentally sound technologies and comply with requirements under environmental laws and regulations.

(2) Every energy management activity must comply with requirements under safety laws and regulations that comprise standardization, installations safety and security, and work safety and security. ${ }^{66}$

The Energy Act does not specifically provide environmental aspects with respect to marine renewable energy. Nevertheless, the above provisions are relevant with and need to be taken into account in the development and management of marine renewable energy.

\footnotetext{
62 Province of Nova Scotia, Marine Renewable Energy Strategy, Halifax: Nova Scotia Department of Energy, 2012 , p. 13.

63 Idem, p. 32

64 The Energy Act, Article 2.

65 The Energy Act, Article 3.i.

66 The Energy Act, Article 8 (1), (2).
} 


\section{The Coastal Zone and Small Islands Act}

As discussed above, the management of marine renewable energy should take into account multiple uses of the ocean since the marine energy utilization may create conflicts with other uses. Therefore, marine renewable energy activities need to be conducted in line with relevant instruments of marine spatial planning, especially The Act No. 27 of 2007 on The Coastal Zone and Small Islands Management, as amended by the Act No. 1 of 2014 (The Coastal Zone and Small Islands Act).

The Act explicitly provides that coastal and small islands resources include waves energy in the coastal area. ${ }^{67}$ In this regard, marine spatial planning is conducted through Rencana Strategis Wilayah Pesisir dan PulauPulau Kecil (RSWP-3-K, or the Strategic Plan on Coastal Zone and Small Islands); Rencana Zonasi Wilayah Pesisir dan Pulau-Pulau Kecil (RZWP3-K, or the Zoning Plan on Coastal Areas and Small Islands); Rencana Pengelolaan Wilayah Pesisir dan Pulau-Pulau Kecil (RPWP-3-K, or the Management Plan on Coastal Zone and Small Islands); and Rencana Aksi Pengelolaan Wilayah Pesisir dan Pulau-Pulau Kecil (RAPWP3-K, or the Action Plan on the Management of Coastal Zone and Small Islands). ${ }^{68}$

The technical aspects related to the management of coastal zone and small islands are further regulated through the Minister of Marine Affairs and Fisheries Regulation No. 34/PERMEN-KP/2014, which provides norms, standards and guidelines for local governments in drafting their management plans on coastal zone and small islands. ${ }^{69}$ However, both the
Coastal Zone and Small Islands Act and the Ministry Regulation have not yet explicitly regulated marine renewable energy activities in the context of coastal zone and small islands management.

\section{The Oceans Act}

The environmental aspects of marine renewable energy activities should also take into account The Act No. 32 of 2014 on Oceans (the Oceans Act). It provides that the national ocean development is based on the policy formulated in a number of important sectors, including: marine resources management; human resources development; safety, security, and law enforcement at sea; governance and institutions; welfare improvement; maritime economy; the management and protection of the marine environment; and maritime culture. $^{70}$

Specifically, the Oceans Act also regulates marine spatial planning, which includes: national marine spatial planning, zoning plan on coastal areas, small islands and sea areas. ${ }^{71}$ It does not explicitly regulate marine renewable energy activities; however, it embodies the main principles on marine spatial planning and protection of the marine environment that are important in marine renewable energy activities.

\section{The Environmental Protection and Management Act}

As previously discussed, marine renewable energy activities may also cause adverse impacts if not properly managed. Thus, such activities must take into account

${ }^{67}$ The Coastal and Small Islands Act, Article 1.4.

${ }^{68}$ The Coastal and Small Islands Act, Article 7 (1).

${ }^{69}$ The Minister of Marine Affairs and Fisheries Regulation No. 34/PERMEN-KP/2014, Article 2.

${ }^{70}$ The Oceans Act, Article 13 (2).

${ }^{71}$ The Oceans Act, Article 43 (1) 
relevant provisions under the Act No. 32 of 2009 on the Environmental Protection and Management (the Environmental Protection and Management Act).

According to this act, every business and/ or activity that causes significant impact to the environment must conduct an environmental impact assessment. ${ }^{72}$ This provision applies to natural resources (living or non-living) exploitation acitivities, which also include the development of marine renewable energy. ${ }^{73}$

It can be concluded that the current national laws basically have provided main principles regarding the environmental aspects of marine renewable energy. Nevertheless, most of these instruments have not specifically addressed procedures that must be taken in protecting and preserving the marine environment within the context of marine renewable energy management.

Thus, a specific legal instrument is urgently needed and it needs to regulate at least the following:

1. A specific environmental impact assessment mechanism for marine renewable energy activities;

2. Marine spatial planning that specifically includes planning on marine renewable energy development areas; and

3. The establishment of safety standards in the construction, location, and operation of marine renewable energy installations.

\section{E. Conclusion}

As the largest archipelagic state in the world, Indonesia holds a pivotal role in developing renewable energy sources, especially marine renewable energy. In this regard, the Indonesian Government needs to address a number of legal issues posed by marine renewable energy activities, especially the protection and preservation of the marine environment. Since Indonesia is a State Party to UNCLOS, it is obliged to take necessary measures to protect and preserve the marine environment. As far as marine renewable energy is concerned, the Indonesian Government needs to ensure that all activities related to the development of marine renewable energy do not cause adverse impacts to the marine environment.

The current laws and policy in Indonesia are still inadequate to regulate the development of marine renewable energy. The National Energy Policy only provides a broad and general policy on renewable energy sources and does not discuss a particular strategy on marine renewable energy. Thus, the Indonesian Government needs to establish a specific policy on marine renewable energy as well as specific laws and regulations to address the environmental impacts that may result from marine renewable energy activities.

\section{References}

\section{Books}

Bird, Robert C. \& Subhas C. Jain, ed., The Global Challenge of Intellectual Property Rights, Edward Elgar, Cheltenham.

Boer Mauna, Hukum Internasional, Pengertian Peranan dan Fungsi Dalam Era Dinamika Global, Edisi ke-2, Alumni, Bandung, 2005. Bradbrook, Adrian, The Development of Renewable Energy Technologies and Energy Efficiency Measures through Public International Law, Oxford University

\footnotetext{
72 The Environmental Protection and Management Act, Article 22 (1).

${ }^{73}$ The Environmental Protection and Management Act, Article 23 (1) b.
} 
Marine Renewable Energy, the Law of the Sea and the Marine Environment: An Indonesian Perspective

Press, 2008.

Crawford, James, Brownlie's Principles of Public International Law, 8th ed, Oxford University Press, Oxford, 2012.

French, Duncan, International Law and Policy of Sustainable Development, Manchester University Press, Manchester, 2005.

Huala Adolf, Dasar-dasar Hukum Kontrak Internasional, Refika Aditama, Bandung, 2009.

Mochtar Kusumaatmadja dam Etty R. Agoes, Pengantar Hukum Internasional, Alumni, Bandung, 2003.

O’Brien, John, International Law, Cavendish Publishing Limited, London, 2001.

Omar bin Yakoob, "Marine Renewable Energy Initiatives in Malaysia and South East Asia", 13th meeting of the United Nations Open-ended Informal Consultative Process on Oceans and the Law of the Sea, New York, 29 Mei-1 Juni, 2012.

Park, Patricia, International Law for Energy and the Environment, Second Edition, CRC Press, Boca Raton, 2013.

Province of Nova Scotia, Marine Renewable Energy Strategy, Nova Scotia Department of Energy, Halifax, 2012.

The Secretary General's High-Level Group on Sustainable Energy for All, Sustainable Energy for All: A Global Action Agenda, New York: United Nations, 2012.

\section{Journals}

Blunden, L.S., A.S. Bahaj, N.S. Aziz, "Tidal Current Power for Indonesia? An Initial Resource Estimation for the Alas Strait", Renewable Energy, 2013.

Bruce, Stuart, "International Law And Renewable Energy: Facilitating Sustainable Energy For All?", Melbourne Journal of International Law, Vol. 14, June 2014.
Derclaye, "Should Patent Law Help Cool the Planet? An inquiry from the point of view of environmental law: Part 1", European Intellectual Property Review.

Esteban, Miguel dan David Leary, "Current Developments and Future Prospects of Offshore Wind and Ocean Energy", Applied Energy, 2012.

Foster, Robert, "Small Wind Turbines May Change the Future of Energy in Developing Countries", Sustainable Development Law and Policy, 2011.

Inger, Richard, et.al., "Marine Renewable Energy: Potential Benefits to Biodiversity? An Urgent Call for Research", Journal of Applied Ecology, 2009.

Leary, David and Miguel Esteban, "Climate Change and Renewable Energy from the Ocean and Tides: Calming the Sea of Regulatory Uncertainty", International Journal of Estuarine and Coastal Law, 2009.

Portman, Michelle E., et.al., "Offshore Wind Energy Development in the Exclusive Economic Zone: Legal and Policy Supports and Impediments in Germany and the US", Energy Policy, 2009.

Rahmat Pramono, "Ketahanan Pangan dan Energi: Peluang Diplomasi Indonesia Dalam Kerangka ASEAN", Jurnal Diplomasi, Vol. 3 No. 3, Kementerian Luar Negeri Republik Indonesia, September 2011.

Shields, Mark A., et.al., "Marine Renewable Energy: The Ecological Implications of Altering the Hydrodynamics of the Marine Environment", Ocean and Coastal Management, 2011.

Thiam, Djiby Racine, "Renewable Energy, Poverty Alleviation and Developing Nations: Evidence from Senegal" Journal of Energy in Southern Africa, 2011. 


\section{Other Documents}

Arora, Ashish, "Intellectual Property Rights and the International Transfer of Technology: Setting out an Agenda for Empirical Research in Developing Countries", The Economics of Intellectual Property, Suggestions for Further Research in Developing Countries with Economies in Transition, Geneva: WIPO, 2009.

Badan Penelitian dan Pengembangan Energi dan Sumber Daya Mineral, Kementerian Energi dan Sumber Daya Mineral, "Potensi Energi Laut Indonesia”, disampaikan di Surabaya, 7 Maret 2014.

Boehlert, George W. and Andrew B. Gill, "Environmental and Ecological Effects of Ocean Renewable Energy Development: A Current Synthesis", 2010.

Boehlert, George W. and Andrew B. Gill, "Environmental and Ecological Effects of Ocean Renewable Energy Development: A Current Synthesis", 2010.

Direktorat Sumber Daya Energi, "Mineral dan Pertambangan Badan Perencanaan Pembangunan Nasional", Policy Paper Keselarasan Kebijakan Energi Nasional (KEN) Dengan Rencana Umum Energi Nasional (RUEN) Dan Rencana Umum Energi Daerah (RUED): Laporan Akhir, 2012.

Humas Ristek, "EBT Arus Laut KOBOLD sebagai Basis Pengembangan Sistem Inovasi Daerah di Lombok Timur, NTB".

I.G, Ngurah Airdha (ed), Kamus Pertambangan, Puslitbang Teknologi Mineral dan Batubara, 2011.

International Energy Agency, "Energy for All: Financing for the Poor," October 2011.
International Energy Agency, Redrawing the Energy-Climate Map: Executive Summary, World Energy Outlook Special Report, Organisation for Economic Co-Operation and Development/International Energy Agency, 10 June 2013.

Kementerian Riset dan Teknologi RI, "Rancangan Peta jalan Regulasi Energi Laut", Jakarta, 2013.

Maizar Rahman, "Ketahanan Energi Kawasan Suatu Keharusan", Harian Suara Karya, 10 Juli 2006.

Policy Paper, "Keselarasan Kebijakan Energi Nasional (KEN), dengan Rencana Umum Energi Nasional (RUEN), DAN Rencana Umum Energi Daerah (RUED)", Bappenas RI, 2012.

United Nations Environment Programme, "Law as an Instrument for Translating the Millennium Development Goals into Action", Background Paper, 2005.

WEHAB Working Group, A Framework for Action on Energy.

Wihatmoko Waskitoaji, Kementerian Riset dan Teknologi R.I. pada Diskusi Kelompok Terarah, "Kebijakan Hukum tentang Energi Laut Terbarukan: Suatu Studi Pendahuluan", 22 Oktober 2014.

\section{Legal Documents}

Environment for the Future We Want (United Nations Environment Programme), 2012. Report of the Open Working Group of the General Assembly on Sustainable Development Goals, UN Doc A/68/970.

Report of the UN Secretary General, Oceans and the Law of the Sea, UN Doc. A/67/79. 